\title{
Analysis of the Performance of National Foreign Exchange Bank in Indonesia
}

\author{
Kahlil Fauzan* and Adi Kuswanto
}

Department of Economics, MMSI, Gunadarma University Depok, Jawa Barat, Indonesia

\begin{abstract}
This research aims to compare the performance of the national foreign exchange bank in 2010-2014 based on the ratio of performance and compliance has been determined by Bank Indonesia. The data used in the research was obtained from annual reports published by the website of the national foreign exchange bank. Period of data using the annual reports National foreign exchange bank in the period December 2010-December 2014. After passing the purposive sample, then a decent sample used as many as 22 National foreign exchange bank recorded in Bank Indonesia.

The results of this research show that the national foreign exchange bank should get special attention from the research by Bank Indonesia is PT Bank Antardaerah, PT Bank Bumi Arta, PT Bank Ekonomi Raharja, PT Bank Ganesha, PT Bank Hana, PT Bank Himpunan Saudara 1906, PT Bank Bumiputra ICB, PT Bank ICBC Indonesia, PT Bank International Indonesia, PT Bank Maspion Indonesia, PT Bank Mega, PT Bank Mestika Dharma, PT Bank of India Indonesia, PT Bank Sinarmas, PT QNB Bank Kesawan. The ratio values are examined on the bank during the years 2010-2014 has a high rating from a rating assessment criteria and should get special attention by Bank Indonesia. Hypothesis testing in this research using MANOVA Test, the results show the value of 13 ratio in the past 5 years (20102014) shows a noticeable difference in the 22 National foreign exchange bank.
\end{abstract}

Keywords: Ratio; Matrix ranking criteria; National foreign exchange bank; Performance; Compliance

\section{Introduction}

Bank has been a partner for societies in order to meet all their financial needs. Bank serve as a place to perform various financial transactions related to such, where securing money, make investments, remittances, make payments or perform billing. Besides, the role of banks greatly affect a country's economic activity. Bank can be regarded as the blood of a country's economy. Therefore, the progress of a bank in one country can also be used as a measure of progress of the country concerned. The more developed a country, the greater the role of banks in controlling the country's economy. In developing countries, an understanding of the new bank piecemeal. Most people only understand the extent of a bank to borrow and borrow money alone. In fact, sometimes some people did not understand the bank as a whole, so the view of the bank often interpreted incorrectly. All this is understandable since the introduction of the banking world as a whole on the community is minimal, so it is not surprising collapse of the banking world is inseparable from his lack of understanding of banking in the country managers in understanding the banking world as a whole.

In this modern world, the role of banks in promoting the economy of a country is very large. Almost all sectors related to various financial activities always require the services of a bank. Therefore, at present and in the future we will not be able to escape from the world of banking, if you want to run a financial activity, whether individuals or institutions, whether social or company. Once the importance of the banking world, so there is a presumption that the bank is a "soul" to drive the economy of a country. This assumption is certainly not wrong, because the function of banks as financial institutions is vital, for example in terms of the creation of money, circulate money, providing money to support business activities, where securing money, where to invest and other financial services. According to Law No. 10 of 1998 is a bank is a business entity that collects and of the community in the form of savings and channel them to the public in the form of credit and/or other forms in order to improve the standard of living of the people.
Bank Indonesia Regulation Number 13/1/PBI/2011 on Rating Bank Chapter 1 Article 2, the Bank is required to maintain and/or improve the health level of the Bank by applying the principles of prudence and risk management in conducting business activities [1]. Bank financial health must be maintained and/or improved so that public confidence in the Bank can be maintained. In addition, the Bank is used as a means to evaluate the condition and problems faced by the Bank and to determine the follow-up to address the weaknesses or issues of the Bank, either in the form of corrective action by the Bank or supervisory action by Bank Indonesia.

The financial ratios required to be reported by the Bank is the ratio of performance and compliance. Performance Ratio consists of the Capital Adequacy Ratio (CAR), Productive Assets Troubled and Nonproductive Assets Troubled to Total Productive and Nonproductive Assets, Productive Assets Troubled to Total Productive Assets, Allowance for Impairment Losses financial assets to productive assets, Gross non-performing loans (NPL), Net Non-Performing Loans (NPL), Return on Assets (ROA), Return on Equity (ROE), Net Interest Margin (NIM), Operating Expenses to Operating Income (ROA), Loan to Deposit Ratio (LDR), Compliance Ratio consists of percentage Violation of the Legal Lending Limit, Percentage Violation of the Legal Lending Limit, Statutory Reserves main rupiah, Net Open

*Corresponding author: Kahlil Fauzan, Department of Economics, MMSI Gunadarma University Depok, Jawa Barat, Indonesia, Tel: +622192116014; E-mail: kahlil_fauzan@rocketmail.com

Received July 21, 2018; Accepted September 12, 2018; Published September 20, 2018

Citation: Fauzan K, Kuswanto A (2018) Analysis of the Performance of National Foreign Exchange Bank in Indonesia. J Glob Econ 6: 308. doi: 10.4172/23754389.1000308

Copyright: $\odot 2018$ Fauzan K, et al. This is an open-access article distributed under the terms of the Creative Commons Attribution License, which permits unrestricted use, distribution, and reproduction in any medium, provided the original author and source are credited. 
Citation: Fauzan K, Kuswanto A (2018) Analysis of the Performance of National Foreign Exchange Bank in Indonesia. J Glob Econ 6: 308 . doi: 10.4172/2375-4389.1000308

Page 2 of 10

Position as whole. This research takes the object on National foreign exchange bank registered at Bank Indonesia.

\section{Methodology}

\section{Type of data}

In conducting this research, the data used is secondary data in the form of historical reports ratios financial ratios of each national foreign exchange bank recorded at Bank Indonesia as well as the financial statements in the form of annual report national foreign exchange bank has been recorded in the Bank Indonesia has been published in the period of December 2010-2014.

\section{Source of data}

From Table 1 data needed in this research is secondary data historically, which is obtained from the Annual Report published by the national foreign exchange bank. Period of data using the annual report national foreign exchange bank period December 2010-December 2014 period is deemed sufficient to follow the development of the Bank's performance because it used the time series data and includes the latest period financial statements annual reports published by bank. Samples were taken by purposive sampling, where samples are used if it meets the following criteria:

Based on the sampling criteria, then the number of samples used in this research were 22 banks. The bank became the sample can be seen more clearly in Table 2.

\section{Result and Discussion}

The object of this research is the entire National foreign exchange bank recorded at Bank Indonesia during the period December 2010-December 2014, but after the purposive sampling, the samples are fit for use (meet the criteria) in this research was 22 national foreign exchange bank recorded at Bank Indonesia. Data taken from the Annual Report of the bank, especially in Financial Ratio Calculation Report. The data on the dynamics of movement performance ratios and compliance with National foreign exchange bank recorded at Bank Indonesia in the period December 2010-2014, there were 13 ratios were assessed in this research and there is a matrix assessment criteria set by Bank Indonesia.

\begin{tabular}{|c|c|c|c|c|c|c|}
\hline & 2010 & 2011 & 2012 & 2013 & 2014 & Total \\
\hline $\begin{array}{l}\text { Total financial statement of National } \\
\text { Foreign Exchange Bank list on } \\
\text { www.bi.go.id (the period December 2010-December 2014). }\end{array}$ & 31 & 31 & 31 & 31 & 31 & 155 \\
\hline $\begin{array}{l}\text { National foreign exchange bank that } \\
\text { provide annual report data and report the } \\
\text { calculation of financial ratios (the period } \\
\text { December 2010-December 2014). }\end{array}$ & 28 & 28 & 28 & 28 & 28 & 144 \\
\hline $\begin{array}{l}\text { National foreign exchange banks which } \\
\text { have total assets of the average total assets } \\
\text { minus the standard deviation of total } \\
\text { assets with the average total assets plus } \\
\text { the standard deviation of total assets } \\
\overline{\mathrm{x}} \text { total assets }-\partial \text { total assets }<x< \\
\overline{\mathrm{x}} \text { total assets }+\partial \text { total assets (the period } \\
\text { December } 2010-\text { December } 2014 \text { ). }\end{array}$ & 22 & 22 & 22 & 22 & 22 & 110 \\
\hline
\end{tabular}

Table 1: Descriptive statistics.

\begin{tabular}{|c|c|}
\hline No. & National foreign exchange bank \\
\hline 1 & PT Bank Antardaerah \\
\hline 2 & PT Bank Artha Graha Internasional \\
\hline 3 & PT Bank Bukopin \\
\hline 5 & PT Bank Bumi Arta \\
\hline 6 & PT Bank Ekonomi Raharja \\
\hline 7 & PT Bank Ganesha \\
\hline 8 & PT Bank Hana \\
\hline 10 & PT Bank Himpunan Saudara 1906 \\
\hline 11 & PT Bank ICB Bumiputera \\
\hline 12 & PT Bank ICBC Indonesia \\
\hline 13 & PT Bank Index Selindo \\
\hline 15 & PT Bank Internasional Indonesia \\
\hline 16 & PT Bank Maspion Indonesia \\
\hline 17 & PT Bank Mayapada Internasional \\
\hline 18 & PT Bank Mega \\
\hline 19 & PT Bank Mestika Dharma \\
\hline 20 & PT Bank Nusantara Parahyangan \\
\hline 22 & PT Bank of India Indonesia \\
\hline & PT Bank SBI Indonesia \\
\hline & PT Bank Sinarmas \\
\hline & PT Bank UOB Indonesia \\
\hline & PT QNB Bank Kesawan \\
\hline
\end{tabular}

Table 2: Research sample. 
Citation: Fauzan K, Kuswanto A (2018) Analysis of the Performance of National Foreign Exchange Bank in Indonesia. J Glob Econ 6: 308. doi: $10.4172 / 2375-4389.1000308$

Page 3 of 10

Based on Rating Criteria Matrix Components of capital, it can be concluded that the 22 National foreign exchange bank very significantly higher and significantly compared to ratios set forth in the provisions of CAR. Rank 1 and rank 2 shows that the Capital Adequacy Fulfilment by 22 National foreign exchange bank have been satisfied with the excellent and good. This indicates that the national foreign exchange bank can finance the total assets to risk capital through the bank itself. In the Figure 1 can be seen that the highest CAR occurred in 2011, namely PT Bank Hana and PT Bank QNB Kesawan is equal to $43.60 \%$ and $45.75 \%$, PT Bank Hana maintain CAR at rank 1 of the year 2010-2014, PT Bank QNB Kesawan has increased from 2010-2011 and 2011- 2014 decreased but the change of CAR at PT Bank QNB Kesawan exhibited significantly higher and were significant enough of the Capital Adequacy ratio that has been determined. Capital Adequacy Ratio of the lowest occurred in 2011 at PT Bank ICB Bumi Putera amounted to $10.12 \%$, this ratio shows the significant value of the Capital Adequacy Ratio that has been determined by Bank Indonesia [2].
Based Matrix Rating Criteria component of KAP, it can be concluded for the quality of productive assets and non-productive the 22 National foreign exchange bank gain special attention is PT Bank ICB Bumiputera and PT Bank SBI Indonesia because the ratio of productive assets and non-productive at PT Bank ICB Bumiputera achieving a rating of 4 , which means the development of the ratio at PT Bank ICB Bumiputera high enough. The ratio in PT Bank SBI Indonesia reached number 4 in 2012 and may imply that the development of the ratio of productive and non-productive assets at PT Bank SBI Indonesia is quite high and should receive special attention by Bank Indonesia. In Figure 2 can be viewed quality of earning assets and non-productive assets to total earning and non-earning assets showed that of PT Bank ICB Bumiputera in 2014 had the highest ratio is $7.33 \%$ and the ratio of this particular attention that gets criteria 4 ranked PT Bank ICB Bumiputera in the last 5 years have always exceeded 3\%, which means moderate growth rates ranging from $5 \%$ to $8 \%$. PT Bank SBI Indonesia has a ratio of $6.44 \%$ in 2012 and belonging to rank 4 that shows the

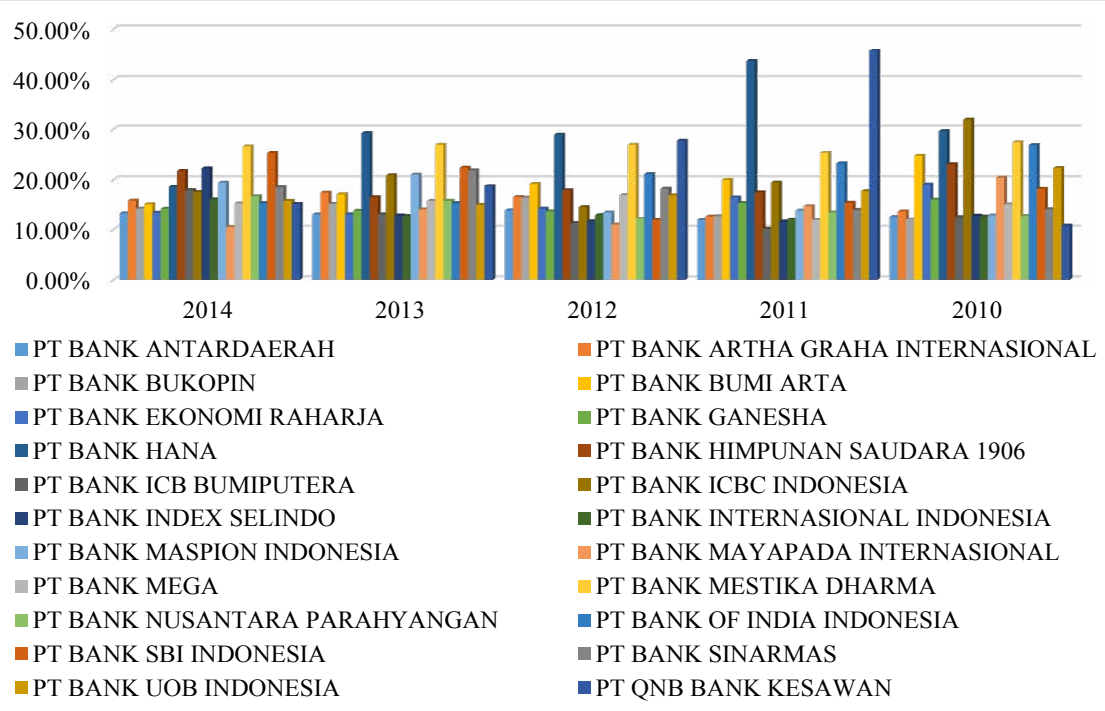

Figure 1: Capital adequacy ratio.

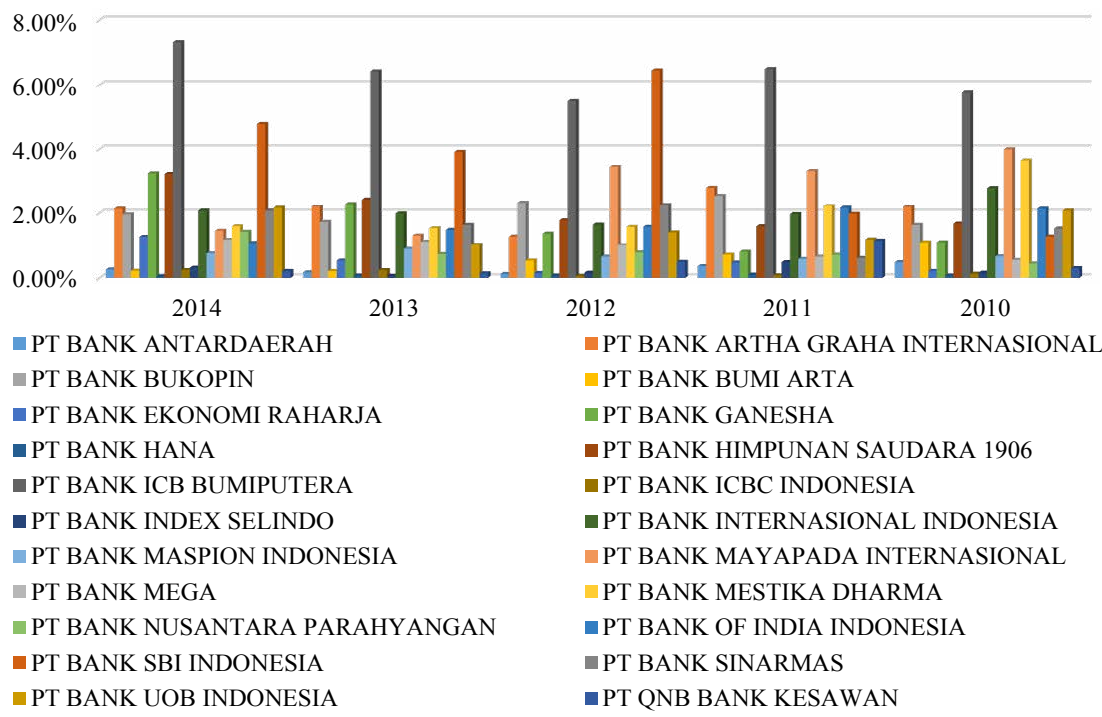

Figure 2: Productive assets troubled and nonproductive assets troubled to total productive and nonproductive assets. 
Citation: Fauzan K, Kuswanto A (2018) Analysis of the Performance of National Foreign Exchange Bank in Indonesia. J Glob Econ 6: 308. doi: $10.4172 / 2375-4389.1000308$

Page 4 of 10

development ratio is high enough to require special attention by Bank Indonesia [3].

Based Matrix Rating Criteria component of KAP, it can be concluded for the quality of productive assets 22 National foreign exchange bank gain special attention is PT Bank ICB Bumiputera and PT Bank SBI Indonesia because the ratio of earning assets in PT Bank ICB Bumiputera achieve a rating of 4 , which can mean the development of the ratio of productive assets troubled in PT Bank ICB Bumiputera high enough. In the Figure 3 can be seen quality of earning assets to total earning assets showed that of PT Bank ICB Bumiputera in 2014 had the highest ratio is $6.67 \%$ and the ratio of this particular attention that gets ranking criteria 4 . The ratio of earning assets Asel to total earning at PT Bank ICB Bumiputera rank 3 and rank 4 in the year 2010 to 2015 , which means the development of the ratio of earning assets is always in the determination of the ratio is quite high and growing [4].

Based on Bank Indonesia Regulation No.14/15/PBI 2012 Chapter V
Assets and Reserves Allowance for impairment losses that commercial banks have to set aside reserves for impairment losses amounting to at least $1 \%$ (one percent) of Productive Assets classified as current [5]. It can be concluded on the 22 National foreign exchange bank that meet this provision in the year 2010-2014 is PT Bank International Indonesia and PT Bank ICB Bumiputera. In Figure 4 can be seen Ratio of Allowance for Impairment Losses against Financial Assets Productive Assets. It can be concluded on the 22 National foreign exchange bank that meet this provision in the year 2010-2014 is PT Bank Internasional Indonesia and PT Bank ICB Bumiputera, 20 National foreign exchange bank others do not meet this provision in the year 2010-2014.

Based on Bank Indonesia Circular Letter No.17/19/DPUM 2015 on Lending by commercial banks or financing and technical assistance within the framework of Development of Micro, Small and Medium Enterprises [6]. This circular contains rules for Conventional Commercial Bank. Conventional Commercial Bank that do not meet

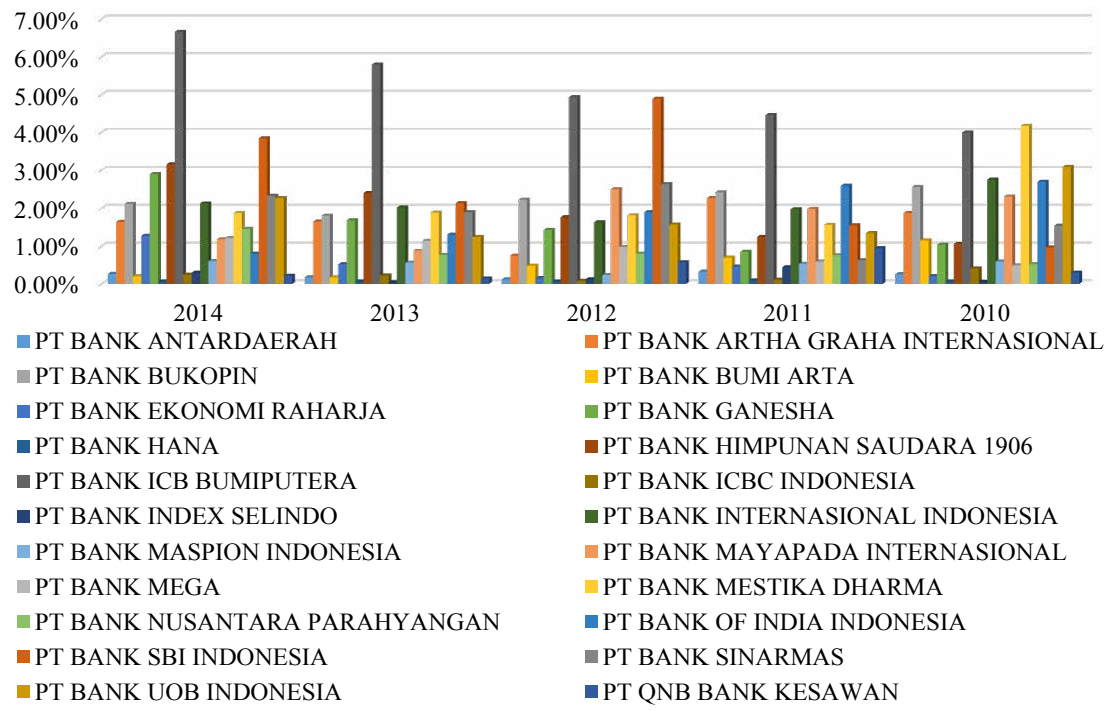

Figure 3: Productive assets troubled to total productive assets.

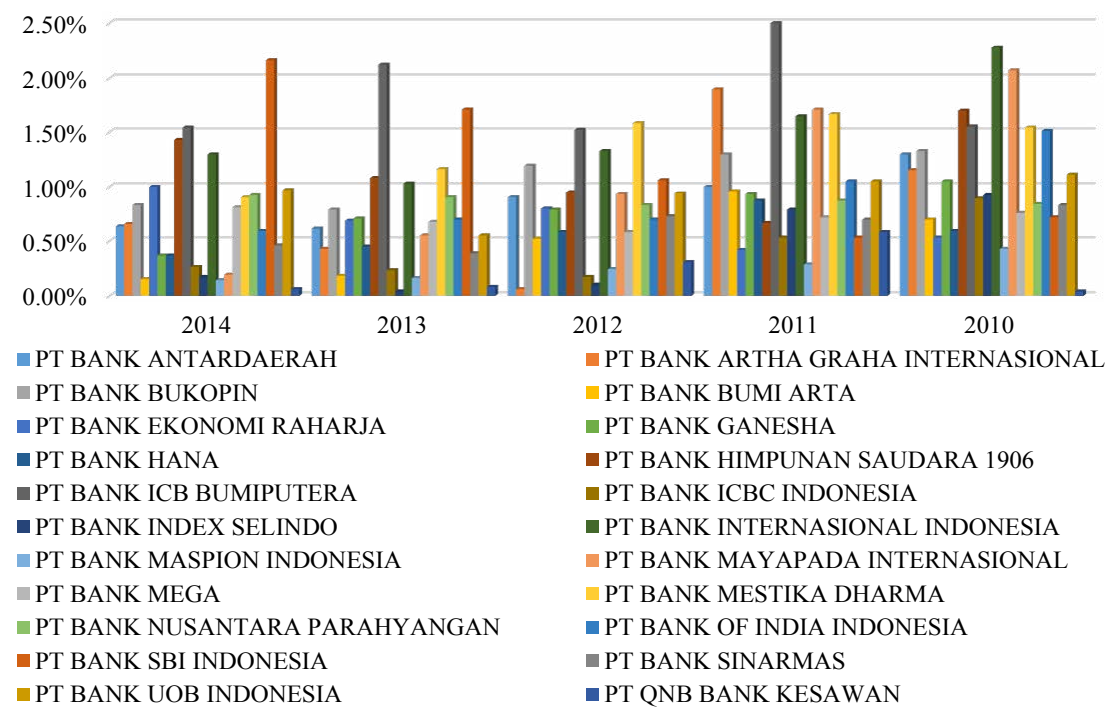

Figure 4: Allowance for impairment losses financial assets to productive assets. 
Citation: Fauzan K, Kuswanto A (2018) Analysis of the Performance of National Foreign Exchange Bank in Indonesia. J Glob Econ 6: 308. doi: $10.4172 / 2375-4389.1000308$

Page 5 of 10

the ratio Credit of Micro, Small and Medium Enterprises or had nonperforming loans in total loans and or the ratio of Non-Performing Loans Credit of Micro Small Medium Enterprises greater than or equal to $5 \%$ (five percent), subject to a reduction in current accounts. In Table 2 , it can be seen that the Bank did not comply with the provisions ratios Loans Small Medium Micro Enterprises or had non-performing loans to total loans is PT Bank ICB Bumiputera, PT Bank Mestika Dharma, PT Bank SBI Indonesia. In Figure 5 above can be seen that the Bank has exceeded 5\% Gross NPL is PT Bank ICB Bumiputera, PT Bank Mestika Dharma, PT Bank SBI Indonesia. PT Bank ICB Bumiputera has a Gross NPL ratio unhealthy in 2014, 2012, and 2011. PT Bank Mestika Dharma has a Gross NPL ratio unhealthy in 2010. PT Bank SBI Indonesia has a Gross NPL ratio is not healthy in 2014 and 2012. Gross NPL is more important to be taken into account rather than Net NPL because the NPL net only take into account the status of credit that has been jammed. While Gross NPL ratio takes into account the credit status of substandard and doubtful, which in the future may increase the status of a jam. The greater the Gross NPL ratio, the more unhealthy Bank, then to PT Bank ICB Bumiputera, PT Bank Mestika Dharma, PT Bank SBI Indonesia imposed the reduction of current account by Bank Indonesia [7,8].

Based on Bank Indonesia Circular Letter No.17/19/DPUM 2015 on Lending by commercial banks or financing and technical assistance within the framework of Development of Micro, Small and Medium Enterprises [6]. In Figure 6 can be seen 22 national foreign exchange bank have Net NPL below 5\%, are in the NPL ratio of the Bank Indonesia provisions according to Bank Indonesia Circular Letter No.17/19/DPUM 2015 [6]. Use of Net Non-Performing Loans as an indicator of the health of the bank is less incentive for banks to maintain credit quality. However, it seems that Bank Indonesia would indeed set very loose conditions. Only banks with net non-perfoming

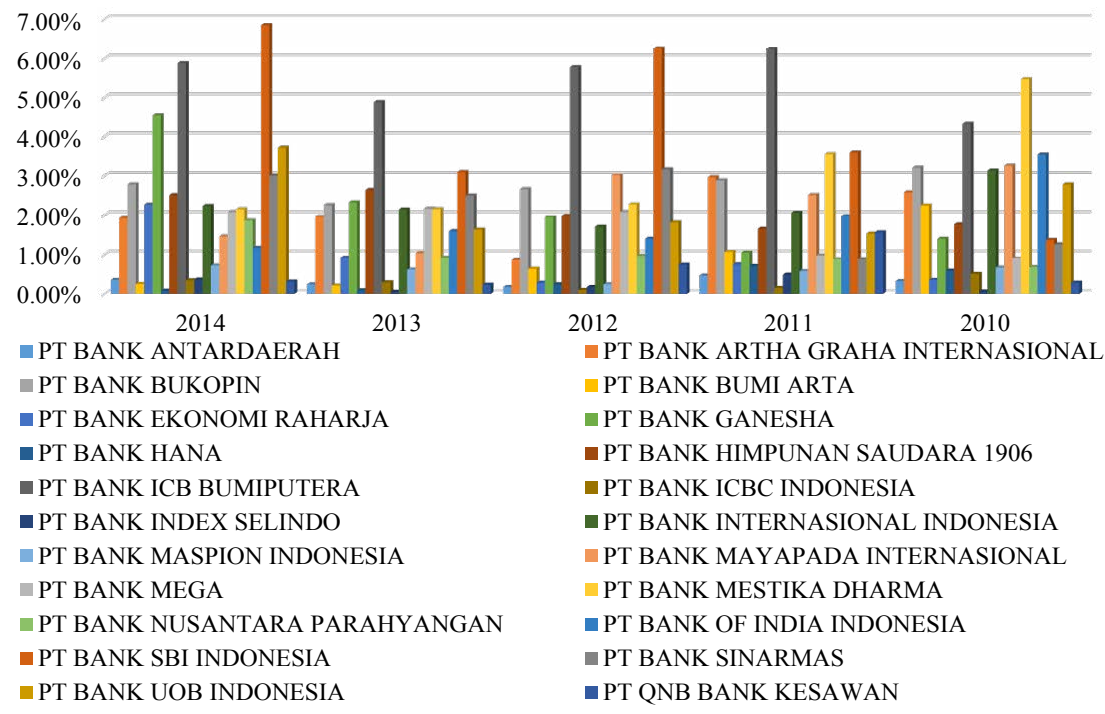

Figure 5: Gross non-performing loans.

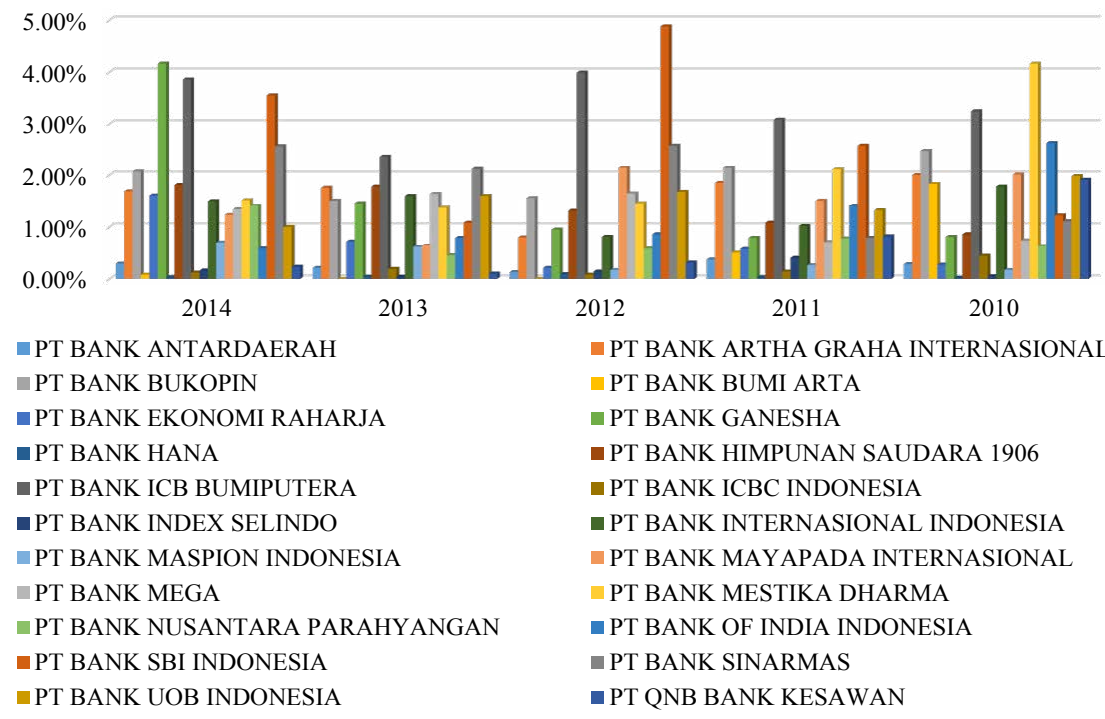

Figure 6: Net non-performing loans. 
Citation: Fauzan K, Kuswanto A (2018) Analysis of the Performance of National Foreign Exchange Bank in Indonesia. J Glob Econ 6: 308 . doi: 10.4172/2375-4389.1000308

Page 6 of 10

Loans above five percent would be treated as a bank which should be in the bank under special surveillance.

Based Matrix Rating Criteria Component ROA, it can be seen at 22 National foreign exchange bank that suffered a loss that is on rank 4 and rank 5 is PT Bank Ekonomi Raharja in 2014 at a value of $0.30 \%$. PT Bank Ganesha in 2014 at a value of 0.21. PT Bank ICB Bumiputera in 2011 to 2014 on the value of $-1.64 \%, 0.09 \%,-0.93 \%,-0.82 \%$ [9]. PT Bank ICBC Indonesia in 2010 at a value of $0.46 \%$. PT Bank International Indenesia in 2014 at a value of $0.41 \%$. PT Bank SBI Indonesia in 2010 at a value of $0.49 \%$. PT Bank QNB Kesawan in 2010-2013 at a value of $0.17 \%, 0.46 \%,-0.81 \%, 0.07 \%$. Rank 4 shows that the profit in the low Bank or likely to suffer a loss (negative leads ROA). A rating of 5 indicates the Bank suffered a great loss (negative ROA). On the other bank indicating the rank 1,2 , and 3 which shows that the profit is very high, higher profits, and profits high enough or ROA ratios ranging from $0.5 \%$ to $1.25 \%$.

Based Matrix Rating Criteria ROE component, it can be seen at 22 National foreign exchange bank that suffered a loss that is on rank 4 and rank 5 is PT Bank Ekonomi Raharja in 2014 with a value of $2.30 \%$. PT Bank Ganesha in 2014 with a value of 1.62\%. PT Bank Hana in 2011 and 2012 with a value of $4.84 \%$ and $4.64 \%$. PT Bank ICB Bumiputera in $2011-2014$ with a value of $-18.96 \%, 0.26 \%,-16.28 \%,-6.69 \%$. PT Bank ICBC Indonesia in 2010-2011 with a value of $2.32 \%, 4.78 \%$. PT Bank Internasional Indonesia in 2014 with a value of $3.91 \%$. PT Bank Maspion Indonesia in 2014 with a value of $4.07 \%$. PT Bank SBI Indonesia in 2010 and 2014 with a value of $2.87 \%$ and $4.32 \%$. PT Bank QNB Kesawan in 2010-2013 with a value of $0.77 \%, 0.72 \%,-3.38 \%$, $0.29 \%$. On the other bank indicating the rank 1,2 , and 3 which shows that the profit is very high, higher profits, and profits high enough or ROE ratios ranging from $5 \%$ to $12.5 \%$ [10].

Based Matrix Rating Criteria Component NIM, it can be seen at 22 National foreign exchange bank that suffered a loss that is at rank 4 is PT Bank Hana in 2011 and 2012 with a value of $1.50 \%$ and $1.44 \%$, which means they net interest margin of the Bank Hana low. 21 Bank another indicating the rank 1,2, and 3 which shows the net interest margin is very high, high, and high enough or NIM ratios ranged from $1.5 \%$ to $2 \%$. In the Figure 7 ratio NIM can be seen national foreign exchange bank which has a net interest margin was very high rated one or ratio NIM above 3\% in 2010-2014 is PT Bank Antardaerah, PT Bank Artha Graha International, PT Bank Bukopin, PT Bank Bumi Arta, PT Bank Ekonomi Raharja, PT Bank Ganesha, PT Bank Himpunan Saudara 1906, PT Bank ICB Bumiputera, PT Bank Index Selindo, PT Bank Internasional Indonesia, PT Bank [11].

Maspion Indonesia, PT Bank Mayapada International, PT Bank Mega, PT Bank Mestika Dharma, PT Bank Nusantara Parahyangan, PT Bank of India Indonesia, PT Bank Sinarmas, PT Bank UOB Indonesia.

From Figure 8 Based Matrix Rating Criteria BOPO component, it can be seen at Figure 922 National foreign exchange bank experiencing poor efficiency levels and very poorly rated 4 and a 5 rating is PT Bank Ekonomi Raharja in 2014 with a value of $97.97 \%$. PT Bank Ganesha in 2011 and 2014 with a value of $96.34 \%$ and $97.82 \%$. PT Bank ICB Bumiputera in 2011-2014 with a value of $114.63 \%$, 99.68\%, $107.77 \%$, 108.54\%. PT Bank QNB Kesawan in 2012 and 2013 with a value of $108.03 \%$ and $100.82 \%$. Another bank that shows the ratio BOPO rated $1,2,3$ which indicates the level of efficiency is very good, good, good enough or ROA ratio ranged from $95 \%$ to $96 \%$.

Based Matrix Rating Criteria Component LDR, it can be seen at 22 National foreign exchange bank that does not have the ability to repay the withdrawal of funds committed funds by depositors rated 4 and a 5 rating is PT Bank Hana in 2011-2014 with a value of 102, $61 \%, 112.25 \%, 126.82 \%, 125.38 \%$. PT Bank Himpunan Saudara 1906 in 2010 and 2014 with a value of $100.20 \%$ and $101.20 \%$. PT Bank Mestika Dharma in 2013 and 2014 with a value of 102.35\%, 101.30\%. PT Bank QNB Kesawan in 2013 with a value of $113.30 \%$. Another bank that showed LDR with a rating of 1,2, 3 which shows the level of ability to repay the withdrawal of funds by depositors is very good, good, and good enough or LDR ranging from $85 \%$ to $100 \%$ [12].

From Figure 10 Based on Bank Indonesia Circular Letter No. 17/17/DKMP/2015, it can be seen in the Table 3 minimum Statutory main rupiah, national foreign exchange bank which do not meet the Primary Statutory Reserves in rupiahs is PT Bank Antardaerah in 2011 with a value of 9.24\% [13]. PT Bank Bumi Arta in 2011 with a value of 9.51\%. PT Bank Ekonomi Raharja in 2011 with a value of $9.01 \%$. PT

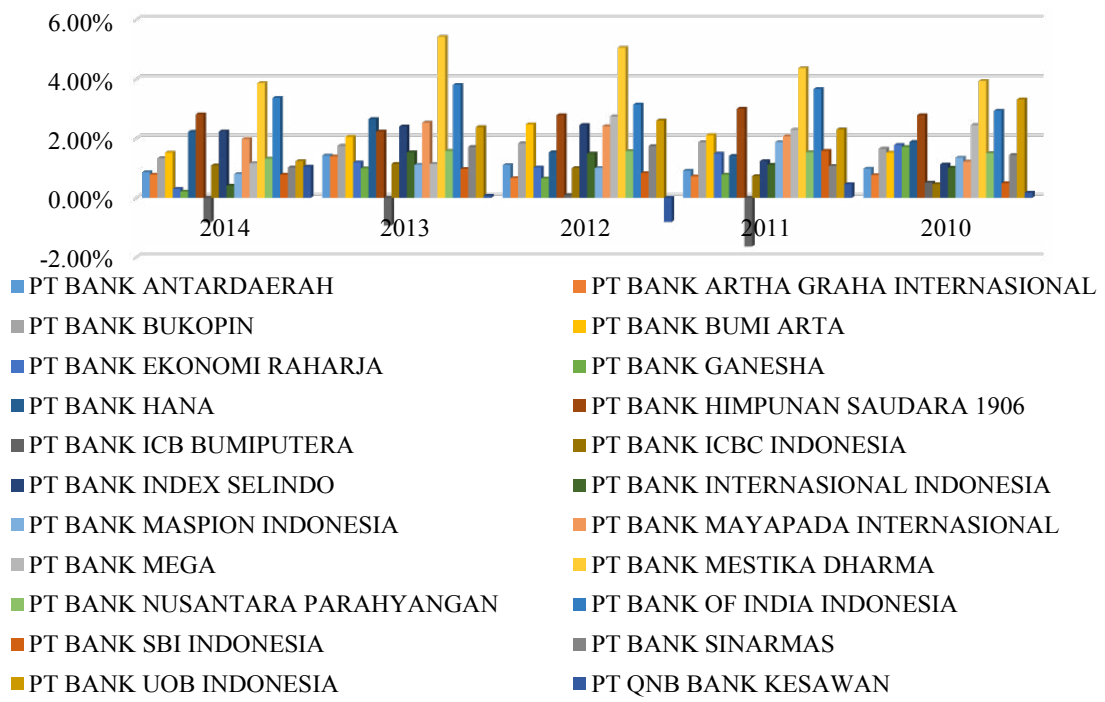

Figure 7: Return on asset. 
Citation: Fauzan K, Kuswanto A (2018) Analysis of the Performance of National Foreign Exchange Bank in Indonesia. J Glob Econ 6: 308 . doi: 10.4172/2375-4389.1000308

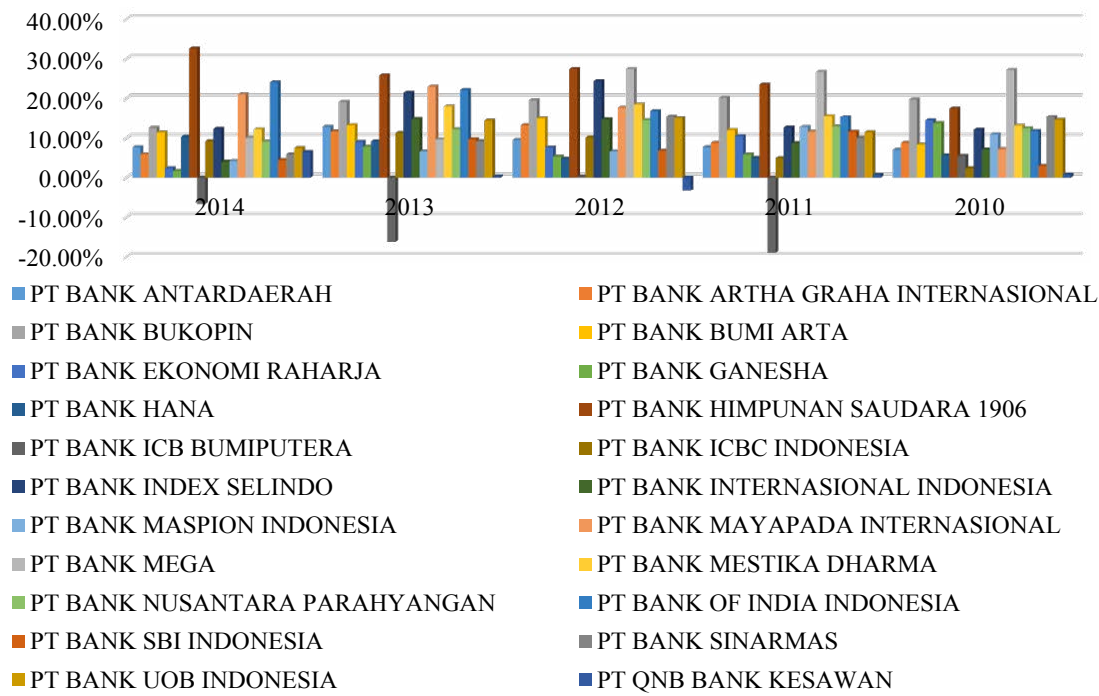

Figure 8: Return on equity.

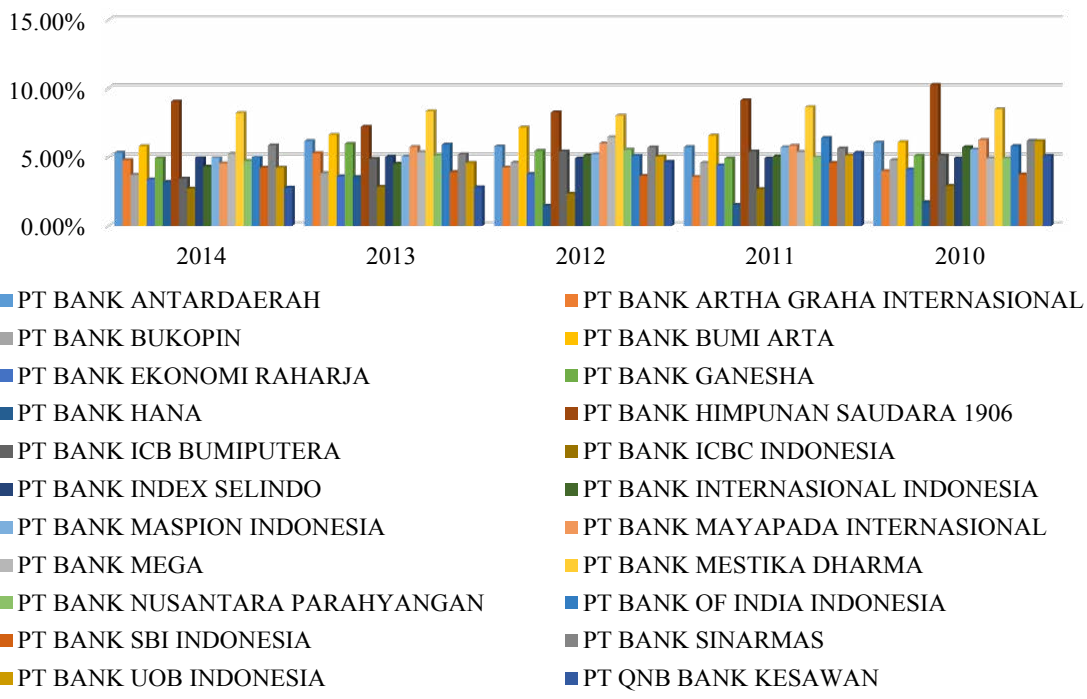

Figure 9: Net interest margin.

\begin{tabular}{|c|c|c|c|c|c|c|c|c|}
\hline Effect & & Value & $\mathbf{F}$ & Hypothesis df & Error df & Sig. & $\begin{array}{l}\text { Noncent. } \\
\text { Parameter }\end{array}$ & $\begin{array}{l}\text { Observed } \\
\text { Power }^{\mathrm{a}}\end{array}$ \\
\hline \multirow[t]{4}{*}{ Intercept } & Pillai's Trace & 1,000 & $13447,166^{b}$ & 13,000 & 76,000 & 0,000 & 174813,160 & 1,000 \\
\hline & Wilks' Lambda & 0,000 & $13447,166^{b}$ & 13,000 & 76,000 & 0,000 & 174813,160 & 1,000 \\
\hline & Hotelling's Trace & 2300,173 & $13447,166^{b}$ & 13,000 & 76,000 & 0,000 & 174813,160 & 1,000 \\
\hline & Roy's Largest Root & 2300,173 & $13447,166^{b}$ & 13,000 & 76,000 & 0,000 & 174813,160 & 1,000 \\
\hline \multirow[t]{4}{*}{ Bank } & Pillai's Trace & 6,063 & 3,663 & 273,000 & 1144,000 & 0,000 & 999,969 & 1,000 \\
\hline & Wilks' Lambda & 0,000 & 5,927 & 273,000 & 880,034 & 0,000 & 1264,628 & 1,000 \\
\hline & Hotelling's Trace & 33,535 & 9,109 & 273,000 & 964,000 & 0,000 & 2486,741 & 1,000 \\
\hline & Roy's Largest Root & 11,376 & $47,672^{\mathrm{c}}$ & 21,000 & 88,000 & 0,000 & 1001,116 & 1,000 \\
\hline
\end{tabular}

Table 3: Multivariate tests ${ }^{\mathrm{d}}$. 
Citation: Fauzan K, Kuswanto A (2018) Analysis of the Performance of National Foreign Exchange Bank in Indonesia. J Glob Econ 6: 308 . doi: $10.4172 / 2375-4389.1000308$

Page 8 of 10

Bank Ganesha in 2011 and 2014 with a value of $9.18 \%$ and $10.17 \%$. PT Bank ICB Bumiputera in 2010 with a value of $9.33 \%$. PT Bank Maspion Indonesia in 2010 with a value of $10.55 \%$. PT Bank Mega in 2012-2014 with a value of $9.95 \%, 9.96 \%, 9.11 \%$. PT Bank Mestika Dharma in 2010 with a value of $10.55 \%$. PT Bank of India Indonesia in the year 2011-2013 with a value of $11.48 \%, 11.38 \%, 12.50 \%$. PT Bank Sinarmas Indonesia in 2011-2013 with a value of 9.24\% 9.45\%, 9.37\% (Figure 11).

From Figure 12 Based on Bank Indonesia Regulation Number 12/10/PBI/2010 on Third Amendment to Bank Indonesia Regulation No. 5/13/PBI/2003 concerning the Net Open Position for Commercial Banks in Article 2 paragraph 1a Banks are required to manage and maintain the Net Open Position at the end of the working day with provision Net Open Position as whole at least 20\% (twenty percent) of the capital [14]. Net Open Position as a whole as referred to in paragraph (1) letter $a$ is the sum of the absolute values of the net difference between assets and liabilities in the balance sheet for each foreign currency the net difference between claims and liabilities which are commitments and contingencies in administrative accounts for each foreign currency are all stated in rupiah (Figure 13).

\section{F test at MANOVA}

F test used to see whether overall if there is a significant effect of group (independent variable) on a set group of dependent variables. Test $\mathrm{F}$ is said to be significant if the p-value 4 that Pillai's Trace Test, Wilks' lambda Test, Hotelling Trace Test, Test Roy's Largest Root Test in Table 3 Multivariate test of less than 0.05, which means significant at the $95 \%$ confidence level. F test at MANOVA also shows that there is not one single multivariate analysis, there are four different types of test. Table 3 below shown Mutlivariate test.

From the result of Table 3 Multivariate Test, $\mathrm{F}$ test for this research can be seen that the dependent variable together showed significant differences in the 22 samples of research data, the time period of 5

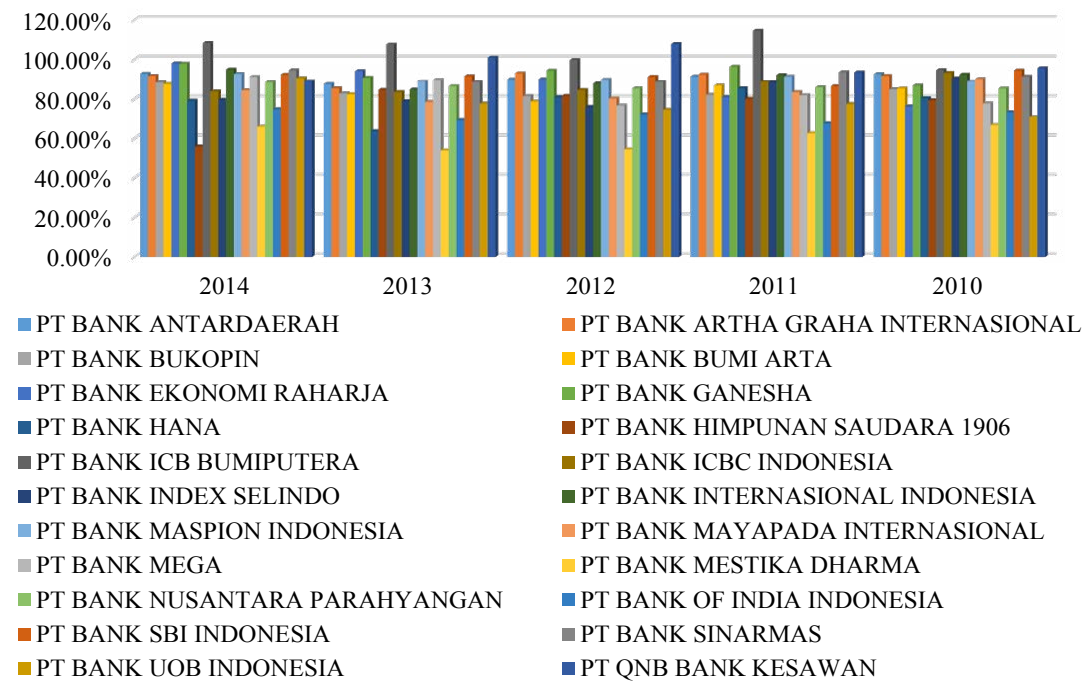

Figure 10: Operational expenses to operational income.

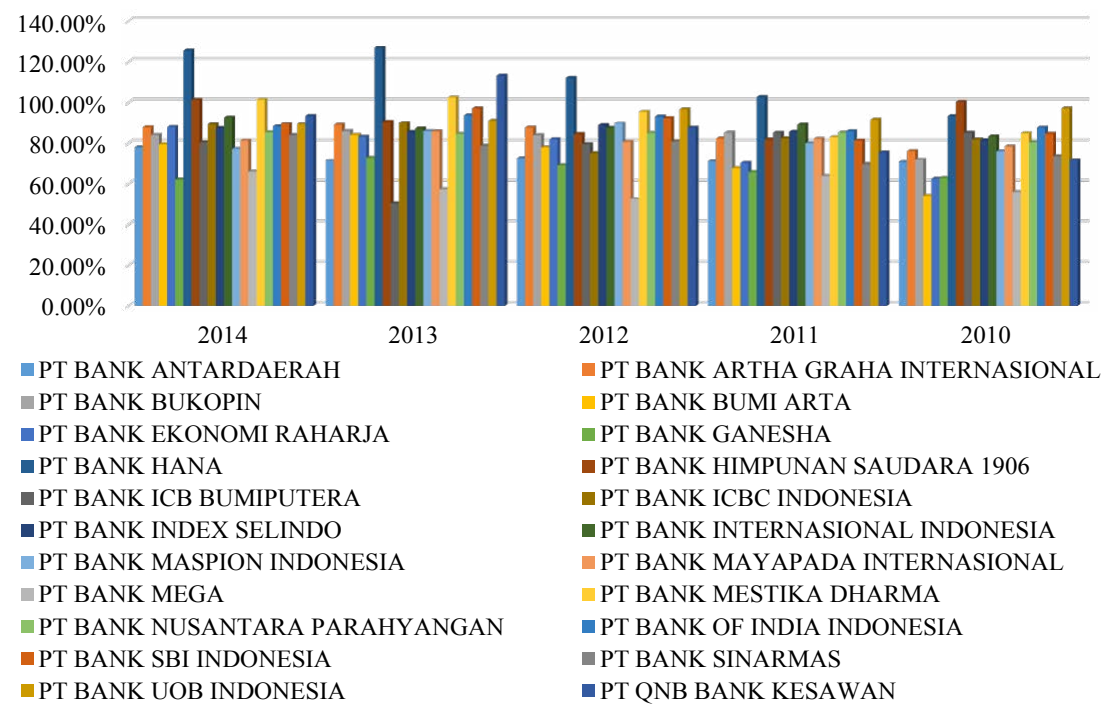

Figure 11: Loan to deposit ratio. 
Citation: Fauzan K, Kuswanto A (2018) Analysis of the Performance of National Foreign Exchange Bank in Indonesia. J Glob Econ 6: 308 . doi: $10.4172 / 2375-4389.1000308$

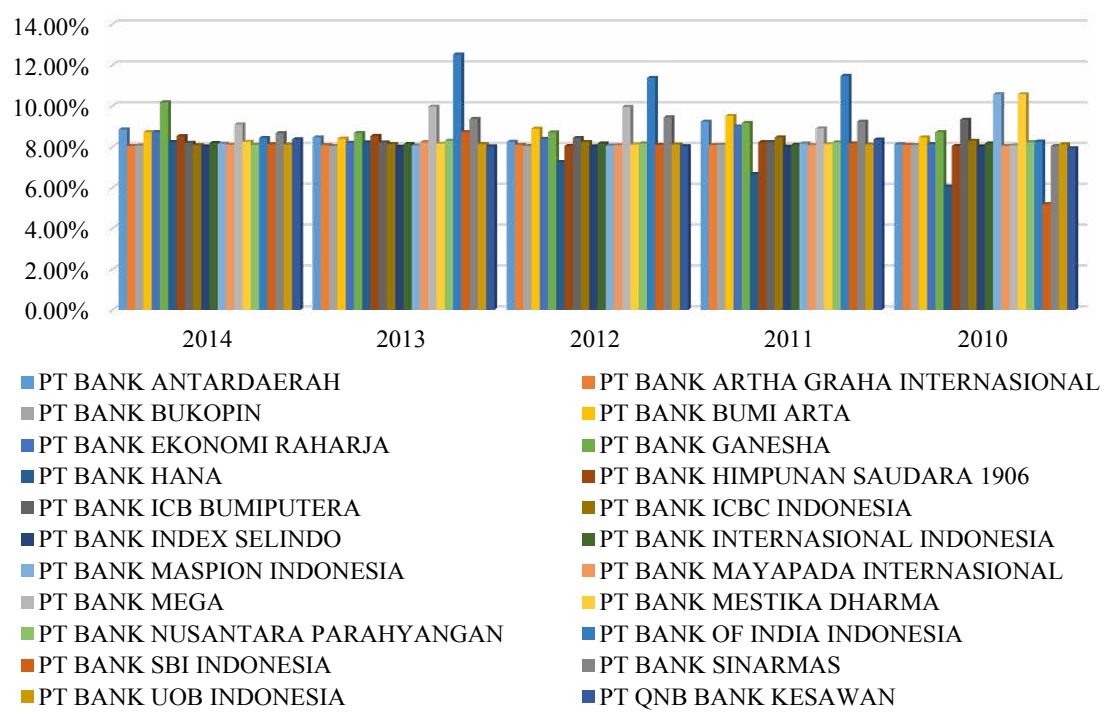

Figure 12: Statutory reserves main rupiah

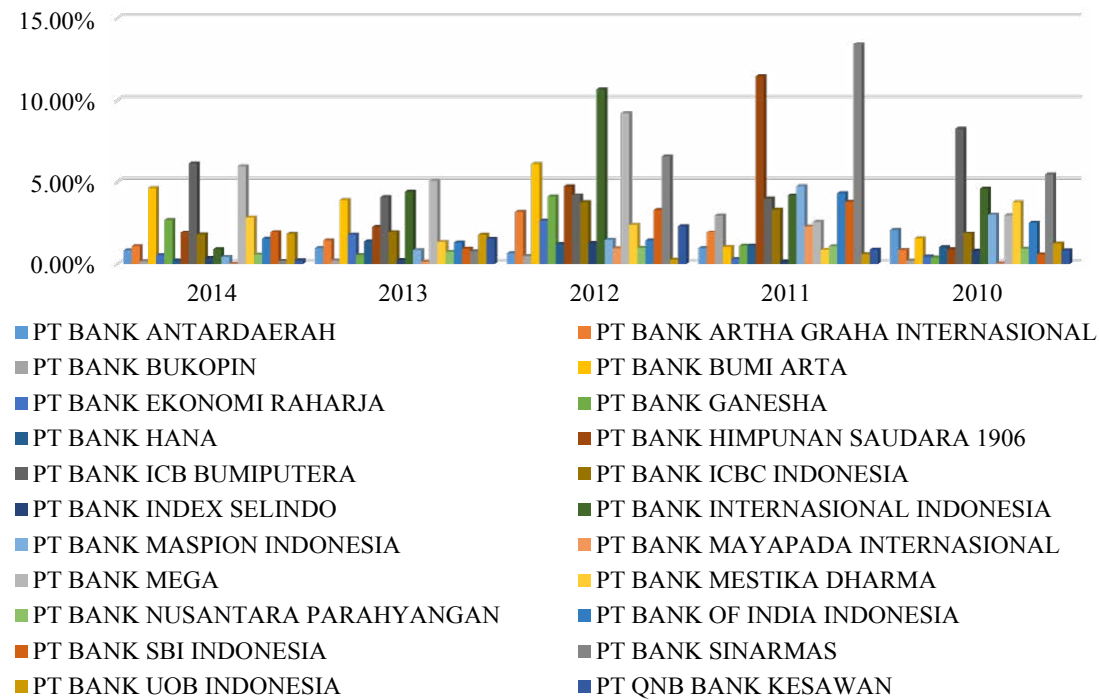

Figure 13: Net open position as whole.

years. This is evident from the value of $\mathrm{F}$ at $4 \mathrm{p}$-value that Pillai's Trace Test, Wilks' lambda Test, Hotelling Trace Test, Roy's Largest Root Test in Multivariate test (Table 3). Pillai's Trace test on the lines of the Bank shows F value of 3.663 with significance of 0.000 . Test Wilks' Lambda on line Bank shows $\mathrm{F}$ value of 5.927 with significance of 0.000 . Hotelling's Trace test on the lines of the Bank shows F value of 9.109 with significance of 0.000 . Roy's Largest Root Test on line Bank shows $\mathrm{F}$ value of 47.672 with a significance of 0.000 . Thereby $\mathrm{H} 0$ rejected and it shows that the ratio of the value of 13 during the period of 5 years (2010-2014) showed significant differences at the 22 National foreign exchange bank $[15,16]$.

$\mathrm{H}_{0}=$ Variable CAR, productive and non-productive assets, Productive Assets, Allowance for Impairment Losses financial assets to productive assets, NPL Gross, NPL Net, ROA, ROE, NIM, BOPO, LDR, Statutory Reserves main rupiah, Net Open Position as whole; together showed no difference in National foreign exchange bank within a period of five years (2010-2014).

Or it could be said, 13 ratios in the period of 5 years (2010-2014) are relatively similar in National foreign exchange bank.

$\mathrm{H}_{1}=$ Variable CAR, productive and non-productive assets, Productive Assets, Allowance for Impairment Losses financial assets to productive assets, NPL Gross, NPL Net, ROA, ROE, NIM, BOPO, LDR, Statutory Reserves main rupiah, Net Open Position as whole together; show the difference in National foreign exchange bank within a period of 5 years (2010-2014) [17].

Or it could be said, 13 ratio in the period of 5 years (2010-2014) is different in National foreign exchange bank.

\section{Criteria for decision}

If the number sig. $>0.05$ then $\mathrm{H} 0$ accepted.

If the number sig. $<0.05$ then $\mathrm{H} 0$ rejected. 


\section{Output}

Consider the Bank row in Table 3, shows that the number of significance was tested by the procedure Pillai 'Trace, Wilk's lambda, Hotelling and Roy's. All procedures showed the significance below 0.05 with the numbers the same significance for each procedure is 0,000 . Thus, $\mathrm{H}_{0}$ rejected [18]. This indicates that the value of 13 ratio in the period of 5 years (2010-2014) showed significant differences at the 22 National foreign exchange bank $[19,20]$.

\section{Conclusion}

Based on the provision Bank Indonesia regarding the rating of the bank, each ratio observed in this research assessed based on the statutes and the Circular Letter of Bank Indonesia shows that the conclusions of this research are as follows:

1. The ratio increased in this research amounted $29.02 \%$ of the data 286 (13 ratio in 22 national foreign exchange banks). Stable ratio in this research amounted to $45.80 \%$ of the data 286 (13 ratio at 22 national foreign exchange bank). Ratio decreased in this research amounted to $25.17 \%$ of the data 286 (13 ratio at 22 national foreign exchange bank). This indicates that the level of performance of the national foreign exchange banks in Indonesia are in Bank Indonesia provisions and there were national foreign exchange banks which are outside the provisions of Bank Indonesia.

2. The ratio in this research has significant differences in the 22 national foreign exchange bank. In Table 3 test of betweensubjects effects showed significant differences in the ratio of 13 tested individually and the results in the Table 3 multivariate test that is test of $\mathrm{F}$ for this research indicate that together 13 ratio showed significant differences in the 22 national foreign exchange bank. This shows that the 22 national foreign exchange banks have different performance in the year 2010-2014.

3. National Foreign Exchange Bank who should receive special attention from this research by Bank Indonesia is PT Bank Antardaerah, PT Bank Bumi Arta, PT Bank Ekonomi Raharja, PT Bank Ganesha, PT Bank Hana, PT Bank Himpunan Saudara 1906, PT Bank ICB Bumiputera, PT Bank ICBC Indonesia, PT Bank Internasional Indonesia, PT Bank Maspion Indonesia, PT Bank Mega, PT Bank Mestika Dharma, PT Bank of India Indonesia, PT Bank Sinarmas, PT Bank QNB Kesawan. The values of the ratio observed in these banks during the years 2010-2014 has ranked high on the ranking criteria and the assessment must receive special attention by Bank Indonesia.

4. National Foreign Exchange Bank that can be categorized as healthy in this research is PT Bank Artha Graha International, PT Bank Bukopin, PT Bank Index Selindo, PT Bank Mayapada International, PT Bank Nusantara Parahyangan, PT Bank UOB Indonesia. The values of the ratio observed in these banks during the years 2010-2014 are in good judgment ranking criteria but do not meet the bank reserve ratio provisions of Financial Assets Impairment Losses to total earning assets in the research period 2010-2014 at least 1\% according to Bank Indonesia Regulation No.14/15/PBI/2012 [5].

\section{Recommendation}

From the findings of this research concluded that during the period of the research, it was revealed that the National Foreign Exchange Bank recorded in Bank Indonesia is less than optimal in the intermediation function, evidenced by the ratio of national foreign exchange bank in ranking high on the ranking criteria of Bank Indonesia. National foreign exchange banks must maintain stability and compliance performance ratio is at Bank Indonesia, the ranking criteria so that the national foreign exchange banks can have a good performance. The bank's performance is important to remember banks manage funds of public funds. Banks that do not have a good performance, not only harm themselves but others. Bank Indonesia as the regulatory and banking supervisors should be advised on improvements. Improvements will include change management, merge such merger, consolidation, acquisition, or even liquidated (dissolved) whereabouts if it is already severe conditions of the bank. Consideration for this depends on the conditions experienced by the bank concerned. If the bank's condition was so severe, but still has some potential, then you should find a way out with a merger with another bank.

\section{References}

1. Bank Indonesia (2011) Peraturan Bank Indonesia Nomor 13/1/PBI/2011 tentang Penilaian Tingkat Kesehatan Bank. Bank Indonesia, Jakarta.

2. Bank Indonesia (2011) Surat Edaran Bank Indonesia Nomor 13/24/DPNP/2011 tentang Penilaian Tingkat Kesehatan Bank. Bank Indonesia, Jakarta.

3. Bank Indonesia (2012) Kodifikasi Peraturan Bank Indonesia Kelembagaan Penilaian Tingkat Kesehatan Bank. Bank Indonesia, Jakarta.

4. Santoso Sigit (2015) Menguasai Statistik Multivariat

5. Konsep Dasar dan Aplikasi dengan SPSS. PT Elex Media Komputindo, Jakarta

6. Bank Indonesia (2012) Peraturan Bank Indonesia Nomor 14/15/PBI/2012 tentang Penilaian Kualitas Aset Bank Umum, Bank Indonesia, Jakarta.

7. Bank Indonesia (2015) Surat Edaran Bank Indonesia Nomor 17/19/DPUM/2015 tentang Pemberian Kredit atau Pembiayaan oleh Bank Umum dan Bantuan Teknis dalam rangka Pengembangan Usaha Mikro, Kecil, dan Menengah. Bank Indonesia, Jakarta.

8. Bank Indonesia (2012) Kodifikasi Peraturan Bank Indonesia Aset Penilaian Kualitas Aset dan Restrukturisasi Pembiayaan. Bank Indonesia, Jakarta.

9. Susilo YS, Triandaru S, Santoso ATB (2000) Banks and Institutions. Other Finance, First Printing, Publisher Salemba Empat, Jakarta.

10. Margianti ES, Hermana B (2011) Manajemen Dana Bank Prinsip dan Regulasi di Indonesia. Universitas Gunadarma, Jakarta.

11. Bank Indonesia (2011) Surat Edaran Bank Indonesia Nomor 13/24/DPNP/2011 tentang Penilaian Tingkat Kesehatan Bank. Bank Indonesia, Jakarta.

12. Husein U (2008) Behavioral Accounting Research Design. PT RajaGrafindo Persada, Jakarta.

13. Persada PTRG (2012) Banking Basics. (Revised edn.), Jakarta.

14. Bank Indonesia (2015) Surat Edaran Bank Indonesia Nomor 17/17/DKMP/2015 tentang Perhitungan Giro Wajib Minimum Bank Umum dalam Rupiah dan Valuta Asing Bagi Bank Umum Konvensional. Bank Indonesia, Jakarta.

15. Bank Indonesia (2010) Peraturan Bank Indonesia Nomor 12/10/PBI/2010 tentang Perubahan Ketiga Atas Peraturan Bank Indonesia Nomor 5/13/ PBI/2003 tentang Posisi Devisa Neto Bank Umum. Bank Indonesia, Jakarta.

16. Imam G (2005) Aplikasi Analisis Multivariate dengan Program SPSS Edisi 3 Badan Penerbit Universita Diponegoro, Semarang.

17. Lukman D (2005) Banking Management. First Printing, Publisher Ghalia Indonesia, Jakarta.

18. Andiko S (2011) Application of the Camels Method in Analyzing Banking Soundness. Gunadarma University, Jakarta.

19. Penman (1991) Financial Statement Information and the Pricing of Earnings Changes. The Accounting Review, 67: 563-577.

20. Damodra NG (1995) Basic Econometrics. (4th edn.), Mc-Grawhill, New York. 